\title{
Different Themes Rendered with Similar Approaches -A Comparison between The Sun Also Rises and The Great Gatsby
}

\author{
Jingnan Shen \\ Changchun University of Science and Technology, Changchun, China \\ Email: shenjingnan1980@163.com
}

\begin{abstract}
In order to get a full understanding of the literary history of the Lost Generation and the society of the 1920's as well, the essay tries to illustrate the decadence of the special time and reflect the problems: disillusion, corruption and failure by extracting some similarities in the aspects of the illustration of decadence and solutions, the biographical features, the description of vices and the arrangement of characters between the two novels: Ernest Hemingway's The Sun Also Rises and Fitzgerald's The Great Gatsby
\end{abstract}

Index Terms-The Sun Also Rises, The Great Gatsby, similarities, the Lost Generation

\section{INTRODUCTION}

Gertrude Stein, the American author who spent most of her adult life in Paris, told the young Ernest Hemingway: "you are all a lost generation" (Ian Ousby, 1981, p.205). Hemingway was struck by the comment and used it as one of the epigraphs to his early novel, Fiesta (called The Sun Also Rises in America). With the success of that book, the phrase passed into popular currency as the label for the group of writers, who had been born near the turn of the century and reached maturity during the First World War. It is used for the novelist of the age: Hemingway himself, F. Scott Fitzgerald, Thomas Wolfe and John Dos Passos. However, among all the works of the lost generation, The Sun Also Rises and The Great Gatsby best show the two main themes of the special period, namely the anti-war emotion and the corruption of "American dream".

After the First World War, a number of intellectuals, poets, artists and writers, who had personally took part in the war, only to find the war a catastrophe and the so-called "crusade for purity and democracy" nothing but a political fraud, became disgusted with war, perplexed and confused for the future. They often took the form of exile and expatriation. Disillusioned with society in general and America in particular, the novelists cultivated a romantic self-absorption. They became precocious experts in tragedy, suffering and anguish. As the first major novel of Ernest Hemingway, who spent most of his adult life in Europe, The Sun Also Rises encapsulates the angst of the post-war generation, known as the Lost Generation. Describing a couple that share a very strange and distant kind of love for each other, Ernest Hemingway showed the aimless lives of the expatriates, and expressed the anti-war emotion in front of readers.

But the nihilism and the suffering were only half the picture. The years following the Great War were also a time of financial boom and extravagance. People's mental world changed tremendously. Traditional morality, ideal and religious belief began to collapse. A group of young adults acted according to their own will and instinct, seeking for unconventional and unrestrained life. F. Scott Fitzgerald was one of them, but he tried to meditate on his life soberly and therefore wrote his finest work The Great Gatsby. Precise and compact in its form, The Great Gatsby gives a finely objective portrait of the hedonistic world in which the Fitzgeralds themselves lived. Capturing both the frantic gaiety and the underlying sadness, it also criticizes the destruction of "American Dream" whose ideal of self-made man has been corrupted by the vulgar pursuit of material happiness.

Though both Ernest Hemingway and F, Scott Fitzgerald chose their own society as their novels' subjects respectively, The Sun Also Roses and The Great Gatsby have much in common. Despite being very different stories, they both illustrate the decadence of the 1920's and reflect the same problems: disillusion, corruption and failure. Moreover they also share many similarities in the biographical features, description of vices and the arrangement of characters. Analyzing them by comparison, we can get a full understanding of the literary history of the Lost Generation, and the society of the special time as well.

\section{Similarities Shared By Both Novels}

\section{A. Similarities in the Illustration of Decadence and Solutions}

When the First World War ended in 1918, the generation of young Americans who had fought the war became intensely disillusioned, as the brutal carnage that they had just faced made the Victorian social morality of 
early-twentieth-century America seem like stuffy empty hypocrisy. The dizzying rise of the stock market in the aftermath of the war led to sudden, sustained increase in the national wealth and a newfound materialism, as people began to spend and consume at unprecedented levels. Against this background, Ernest Hemingway and F. Scott Fitzgerald wrote The Sun Also Rises and The Great Gatsby respectively, which, despite the different themes, illustrate the decadence in the 1920's and show the decline of the moral values. At the same time, by depicting Jake's perseverance in The Sun Also Rises and Nick's return to the west in The Great Gatsby, Hemingway and Fitzgerald left a glimmer of hope in front of readers.

\section{Decadence and solution illustrated in The Sun Also Rises}

In the novel The Sun Also Rises, Ernest Hemingway describes a couple that share a very strange and distant kind of love for each other. This story takes place immediately after the First World War, a time of great hardship. This hardship results in a degradation of values both morally and socially. The love that Brett and Jake share is symbolic of the general decline in values in that they tolerate behaviors in one another that would have been previously considered unacceptable. Jake, who is left impotent by an ambiguous accident during the First World War, is forced to keep the relationship strictly platonic and stand watching as different men float in and out of Lady Ashley's life and bed. Hemingway shows war as the destroyer of love. What's more, without the old certainties undercut by the First World War to rely on, Jake, Brett, and their acquaintances fill their time with inconsequential and escapist activities, such as drinking, dancing and debauchery. Very often their merry-making is joyless and driven by alcohol. Although they spend nearly all of their time partying in one place or another, nearly all the characters remain sorrowful or unfulfilled. Hence their drinking and dancing is just a futile distraction, a purposeless activity characteristic of a wondering, aimless life. The proclaimed "crusade war" destroys the generation's world, both mentally and physically.

However, Jake, the narrator and main character of The Sun Also Rises is a man of action who spends more time achieving goals than talking them. Though his physical wound ascends into an emotional one by preventing him from ever consummating his love with Lady Ashley, he knows when to control himself, relies solely on himself, utilizes his assets, and enjoys bullfights and other honorable activities. These characteristics reveal his strong character built of courage and grace. At the end of the story, "I settled back, Brett moved close to me. We sat close against each other. I put my arms around her and she rested against me comfortably" (Ernest Hemingway, 2000, p.251). This setting in a cab symbolizes Jake's returning to principle. Jack was once at a loss, but he has never sunk into it. He seems aware of the fruitlessness of the generation's way of living. From the beginning to the end, he is clearly conscious of the embarrassing situation and tries to seek the solutions. Though the story ends without a clear answer, friendship, stoicism and natural grace under pressure are offered as the values that matter in an otherwise amoral often-senseless world.

\section{Decadence and solution illustrated in The Great Gatsby}

The Great Gatsby, a story of the thwarted love between a man and a woman, is one of the greatest literary documents of 1920's, in which the American economy soared, bringing unprecedented levels of prosperity to the nation. Prohibition, at the same time, made millionaires out of bootleggers, and an underground culture of revelry sprang up. The chaos and violence of the First World War left America in a state of shock, and the generation that fought the war turned to wild and extravagant living to compensate. "The staid conservatism and time-worn values of the previous decade were turned on their ear, as money, opulence, and exuberance became the order of the day" (Weiren Wu, 1990, p.163). Fitzgerald positions the characters of The Great Gatsby as emblems of these social trends. He portrays the 1920 's as an era of decayed social and moral values, evidenced in its overarching cynicism, greed, and empty pursuit of pleasure. The reckless jubilance that led to decadent parties and wild Jazz music-epitomized in The Great Gatsby in the opulent parties that Gatsby throws every Saturday night-resulted ultimately in the corruption of the American Dream, as the unrestrained desire for money and pleasure. The American dream was originally about discovery, individualism, and the pursuit of happiness. In the 1920's, however, easy money and relaxed values have corrupted this dream, especially on the East Coast. In The Great Gatsby, Gatsby instills Daisy with a kind of idealized perfection that she neither deserves nor possesses, and when his dream crumbles, all that is left for Gatsby to do is die. Gatsby's dream is ruined by the unworthiness of its object, just as the American dream in the 1920's is ruined by the unworthiness of its subject-money and pleasure.

In The Great Gatsby, Fitzgerald also uses the contrasting image of the East and Midwest to develop his critique; the East denotes the place where the corruption of the American dream has occurred. Finally at the end of the novel, Nick, the narrator and observer of the corruption, decides to move back to Minnesota, where American values have not decayed. Nick learns that this place of dishonesty, lack of morale and lack of values is not the place for him. The dream has been destroyed and polluted by the pursuit of material success. Fitzgerald shows that the secret of truly happiness in life is to fulfill the American dream purely and faithfully.

Portraying the decadence of the 1920's, the authors, two World War I veteran themselves, show keen insight into the lives and minds of Americans who fought in Europe during the conflict and the experience Americans may have had in the years following their return. Through written conversation, the novels deal with many of the social attitudes and ideas, which prevailed during the early1920's, and offer a solution respectively.

\section{B. Similarities in the Biographical Features}

The writers, Ernest Hemingway and F. Scott Fitzgerald, both include biographical features in their novels The Sun Also Rises and The Great Gatsby. Although The Sun Also Rises is more closely related to actual events in Hemingway's 
life than The Great Gatsby is to events in Fitzgerald's life, they both take the same approach. Ernest Hemingway comments on the effects of the First World War on the Lost Generation and the hope for the future in the next generation. Fitzgerald comments on the jaded old-wealth society of the Eastern United States and the corruption of the American dream. By adding biographical features into their novels, both Ernest Hemingway and F. Scott Fitzgerald are able to give their novels that extra depth because the plots of the novels are more realistic and accurately reflect the society of the time.

\section{Biographical features in The Sun Also Rises}

Hemingway's novel is almost entirely based on actual events that happened to Hemingway and a group of his friends. This enhances the realism of The Sun Also Rises which is based on real people and their fiesta in Pamplona. During Ernest's third trip to Pamplona, his company would stay at Juanito Quinata's hotel, Quinatana. Juanito was a veteran aficionado and matadors often stayed there. The similarities in name are unmistakable and the character in the novel is a veteran aficionado as well. More importantly, there they met Ordonez, a matador, like the Pedro from the novel; he fought in the "old manner" and "on several bulls, killed "Recibiendo" (Carlos Baker, 1969, p.147) and was hailed as the "messiah who had come to save bullfighting" (Carlos Baker, 1969, p. 147). Pedro Romero is an important symbol of hope in the novel. Ordonez, thinly disguised as Pedro Romero, was beginning to dominate the book. Another important character in the book, Brett, is based on a real life participant in Hemingway's Pamplona, Duff Twysden. She is physically similar to Brett. Like Brett, "she wore a man's felt hat" (Carlos Baker, 1969, p. 146). Brett and Robert Cohn once go on a trip together where they romanced together unknown to anyone else. Similarly, Harold Loeb (Robert Cohn) told Ernest that he wanted to relax by the sea at St. Jean-de-luz before joining the others at Burgette. What he did not reveal was that he had persuaded Duff Twysden to spend a week with him in consummation of their romance. The scene where Brett received the bull's ear from Pedro actually happened. Just not to her parallel Duff Twysden, Ordonez gave the ear to Hemingway's wife Hadley. Similarly as his counterpart Robert Cohn in the novel, Harold Loeb was treated as an outcast due to his relationship with Duff and his constant following her around. In the novel, Mike constantly brandishes Robert with remarks of how he is not wanted and how he cannot see that. In Hemingway's actual trip, Harold Loeb and Duff slipped away for a drink in one of the small cafes and ended up in a Spanish clubroom where she refused to leave and Harold was forced to leave alone. The next day Guithrie (Mike) suddenly told Harold to get out: he was not wanted. Besides being based on real people and their fiesta in Pamplona, The Sun Also Rises contains scenes on the Irati River. Perhaps, in his novel Hemingway portrays the vacation on the Irati River as how he wanted to experience it. But in reality, “The dark stream of the Irati was filled with logger's trash" (Carlos Baker, 1969, p. 143), and Hemingway and his friends Bill Smith were unable to catch a single fish after four days of trying.

\section{Biographical features in The Great Gatsby}

The story in Fitzgerald's book, however, contains basic ideas from his life, not necessarily actual events. In this novel, Fitzgerald is able to write about his experience from a different perspective and include his self both in the characters of Jay Gatsby and Nick Carraway. As in many of Fitzgerald's works, he writes about a "golden girl", the desire of every man that he couldn't have. In the case of The Great Gatsby, Fitzgerald creates the character of Daisy to fit his description. In actuality the motivation for Fitzgerald's writing about the golden girl came from real events. Ginevra King was the love of young Fitzgerald. In Ginevra's eyes, however, Fitzgerald was simply one of the many men in her young life and when it came time, she dropped him. In The Great Gatsby, Daisy is shown by the end to be a very careless and confused one, who "smashed up things and creatures and then retreated back into their money or their vast carelessness... and let other people clean up the mass they had made" (F. Scott Fitzgerald, 1992, p.180). This statement from the novel relates to Fitzgerald's own feeling for Ginevra who used him, then dropped him when it came time, leaving Francis devastated. The romance between Fitzgerald and Ginevra King is also given meaning in The Great Gatsby as Givevra King and Fitzgerald himself came from different social worlds just as Daisy and young poor Gatsby did. In both situations, the woman came from the aristocratic "old money" rich and the guys were respectively poor in comparison. On the other hand, like Fitzgerald, Nick Carraway is a thoughtful young man from Minnesota, educated at Yale, who moves to New York after the war. Also similar to Fitzgerald is Jay Gatsby, a sensitive young man who idolizes wealth and luxury and who falls in love with a beautiful young woman while stationed at a military camp. Having become a celebrity, Fitzgerald fell into a wild, reckless lifestyle of parties and decadence, while desperately trying to please his wife Zelda, who delayed their wedding until he could prove a success, by writing to earn money. Similarly, Gatsby amasses a great deal of wealth at a relatively young age, and devotes himself to acquiring possessions and throwing parties that he believes will enable him to win Daisy's love. Like Nick in The Great Gatsby, Fitzgerald found this new lifestyle seductive and exciting, and like Gatsby, he had always idolized the very rich. Now he found himself in an era in which unrestrained materialism set the tone of society, particularly in the large cities of the East. Even so, like Nick, Fitzgerald saw through the glitter of the Jazz Age to the moral emptiness and hypocrisy beneath, and part of him longed for this absent moral center. In many ways, The Great Gatsby represents Fitzgerald's attempt to confront his conflicting feeling about the Jazz Age. Like Gatsby, Fitzgerald was driven by his love for a woman who symbolized everything he wanted, even as she led him toward everything he despised.

By providing biographical information in their novels, Ernest Hemingway and F. Scott Fitzgerald are able to enhance the meaning of their work and provide extra credibility and realism into their plots. Fitzgerald takes a rejection from his life and uses that idea to write a social commentary on the corruption of the American dream by the old-rich of the 
Eastern United States. Hemingway takes actual events from his life and uses that as a basis for the plot of his novel, this enhances the theme by describing the effect of the First World War on Hemingway's generation.

\section{Similarities in the Description of Vices}

In the 1920's, America was going through many changes, evolving from the Victorian period to the Jazz Age. The Great War was over in 1918; men who returned from the war had the scars of war imprinted in their minds. Despite the eighteenth amendment, which prohibited the manufacture, sale or transportation of liquor in the United States, most people think of large, lavish parties when thinking about the 1920's. Both Ernest Hemingway and F. Scott Fitzgerald examining the evils of the time and the consequences that accompanied the actions of the characters, there are thus parallels between the vices in The Sun Also Rises and the vices in The Great Gatsby: namely excessive alcohol consumption, sexual promiscuity and the power of money.

\section{Excessive alcohol consumption}

In The Sun Also Rises, nearly all of Jake's friends are alcoholics. Whether it is day or night, wherever they happen to be, they drink, usually to excess. Hemingway clearly portrays the drawbacks to this excessive drinking alcohol frequently, which brings out the worst in characters, particularly Mike. He shows himself to be a nasty, violent man when he is intoxicated. More subtly, Hemingway also implies that drunkenness worsens the mental and emotional turmoil that Jake and his friends live with. In comparison, many of the characters of The Great Gatsby drank excessively, despite the prohibition issued in the United States. Jay Gatsby, a bootlegger, throws large lavish parties at his grand estate during the summer evenings, where the alcohol, food and music flows. Characters such as Tom and Daisy Buchanan, Myrtle Wilson, Jordan Baker and Nick Carraway enjoy parties and drank excessively. Another important similarity to point out under the excessive drinking is the fact that both Hemingway and Fitzgerald drank excessively. It is their behaviors that caused their vivid writing of the evil of excessive alcohol consumption.

\section{Sexual promiscuity}

The second parallel is the vice of sexual promiscuity. Both Hemingway and Fitzgerald portray the destructiveness of sex in their works to show the decline of moral standards. The most promiscuous character in The Sun Also Rises is Brett Ashley. Throughout the book, Brett and Barnes flirt a lot and they also kiss several times. Brett not only has affair and sleeps with Cohn at San Sebastian, but also chooses to flirt and lead on Count Mippipopulous. She also has another affair with Pedro the bullfighter. This whole time she is engaged to marry Mike. They are not married, yet they sleep together, this didn't happen a lot before the war. In comparison, The Great Gatsby has promiscuous behaviors in the form of adultery. Tom Buchanan has several affairs since he and Daisy have been married. His affair with Myrtle Wilson is highlighted by Fitzgerald. Gatsby and Daisy were lovers before he went to the Great War. When they were reunited, they became inseparable, a lost love found. However, under the superficial pleasure and happiness, love is tarnished and the decline of moral values is showed.

\section{Power of money}

The third parallel between a vice in The Sun Also Rises and a vice in The Great Gatsby is that of the power of money. In The Sun Also Rises, Jake Barns has an established bank account. He is able to live in Paris, travel in Europe, and enjoy his dining and drinking experiences. He is able to buy friends as is stated in the text, "No one makes things complicated by becoming your friend for any obscure reason. If you want people to like you, you have to spend a little money." (Ernest Hemingway, 2000, p.237) Perhaps it is Jake's money that attracted Brett to him. In comparison, in The Great Gatsby, Tom Buchanan and Jay Gatsby are men of great wealth who has bought power. Tom has great control over Daisy, Myrtle and George. He tries to control Nick and Gatsby, but does not succeed. Gatsby cannot be controlled by Tom's money; rather he is controlled by Daisy. Gatsby tries to buy back a period of time, back to when he and Daisy were first in love. She did not wait for hem because he was poor at that time. She told him that rich girls didn't marry poor boys. The real irony for Gatsby is that with all of his money and all the people he knew through business contacts and the many parties he had thrown, only Nick and his father attend his funeral. Money brings nothing but false friendship and love. The more lasting and lofty pursuit should be the richness of morality instead of money

\section{Similarities in the Arrangement of Characters}

Sharing the same sort of yielding relationships and unending searches for love and happiness, all of which unfailingly end in tragedy, it is not surprising that the characters in The Sun Also Rises and The Great Gatsby have very similar traits. Characters that are similar and would be corresponding in both books would be, Jake and Nick, Brett and Daisy, Robert and Gatsby, Mike and Tom.

Both stories are told through the use of non-judgmental narrators to comment on the lost generation. In The Sun Also Rises, this man is Jake Barnes, while in The Great Gatsby this man is Nick Carraway. Both men are thrown into social situation where they feel awkward and don't want to interfere, and so through the authors' use of these men, the reader is left with a more or less unbiased view of the bizarre social structures and dramas that permeated the society in this era. Though Jake is involved in the love affairs in The Sun Also Rises, while Nick doesn't, both men are tolerating, open-minded, quiet and a good listener, and, as a result, others tend to talk to them and tell them their secrets. On the other hand, Nick, like Jake, is lost and has no idea on how to live his life. Their days are spent hanging out with friends all day and night.

It is also reasonably clear that Cohn and Gatsby share many notable characteristics, too. Both spend their days 
dreaming of their associated mistresses, and both share a love of professionalism, honor and romance. Each man sees himself as a sort of savior to his darling, to save her from the world and from all those who are unworthy. Yet still in both cases, their dreams are shattered by a less than devotional love which they receive in return. Both men are henceforth removed from the story and quickly both are forgotten.

Further comparison of character includes Brett and Daisy, who use man to get what they want as they search for destined love. However, neither of them seems to know what love is. Brett can only relate to having sex, and Daisy thinks chiefly convenience. Yet at the same time, they are surrounded by men who love them. Brett is a strong, largely independent woman. She exerts great power over the men around her, as her beauty and charisma seem to charm everyone she meets. Yet she refuses to commit to any man. Daisy is in love with money, ease, and material luxury. She is capable of affection (she seems genuinely fond of Nick and occasionally seems to love Gatsby), but not of sustained loyalty or care.

Characters that are also similar would be Mike and Tom. Though they have different social attitudes and positions, both share a mistreatment of their wives (or fiancée in Mike's case), and a dislike for their rivals. Yet in both cases, after all has been done, Brett reluctantly returns to Mike, and Daisy reluctantly returns to Tom.

\section{CONCLUSION}

Having compared Ernest Hemingway's The Sun Also Rises and F. Scott Fitzgerald's The Great Gatsby, we are able to see that the themes in The Sun Also Rises and The Great Gatsby are rendered with similar approaches. The Sun Also Rises and The Great Gatsby are created to voice the authors' indignation against the First World War and the disappointment in the American Dream respectively, but both the writers try to face their own society and times in their keen insight and observe the life with calmness to reveal the problems of the 1920's. The novels not only include biographical features to increase the credibility and realism, but also describe similar vices and arrange corresponding characters to enhance readers' understanding of the special period. And with these approaches, the writers are able to portray the mental and physical wound caused by the First World War, and the American Dream corrupted by vulgar pursuit of material happiness, with great truthfulness, minuteness, and vividness.

The Lost Generation is only a brief chapter in American literary history. Its characteristic blend of public suffering and private pleasure begins to disappear with the onset of the 1930's, but as the leading works of the Lost Generation, The Sun Also Rises and The Great Gatsby break the restrains of traditional writing methods, adopt a compact and concise style, and thus establish the position of the Lost Generation in the world literary history.

\section{REFERENCES}

[1] Baker, Carlos. (1969). Ernest Hemingway, a Life Story. New York: Charles Scribner's Sons.

[2] Cunliffe, Marcus. (1977). The Literature of the United States. New York: Frederick Ungar Publishing Co., Inc.

[3] Donaldson, Scott. (1983). Fool for Love. New York: Dell Publishing.

[4] Fitzgerald, F. Scott.( 1992). The Great Gatsby. Beijing: Foreign Language Teaching and Reach Press.

[5] Hemingway, Ernest. (2000). The Sun Also Rises. Nanjing: Yilin Press.

[6] McMichael, George. (1983). Anthology of American Literature, $2^{\text {nd }}$ Ed.. New York: Doubleday Company Inc.

[7] Ousby, Ian. (1979). A Reader's Guide to Fifty American Novels. London: Heinemann Educational Books Ltd.

[8] Vinson, James. (1983). Novelists and Prose Writers. New York: McGrowhill Book Company.

[9] Wu, Weiren. (1990). History and Anthology of American Literature, Vol.2. Beijing: Foreign Language Teaching and Research Press.

Jingnan Shen was born in Tieling, Liaoning province, China in 1980. She received Master's degree in foreign linguistics and applied linguistics from Changchun University of Science and Technology, China in 2006.

She is currently a lecturer in the Foreign Languages College, Changchun University of Science and Technology, Changchun, China. Her research interests include English language teaching and literature. 